\title{
Operation Mechanism of Certification Market Based on the Theory of Two Sided Markets: Take ISO9000 Certification Market as an Example
}

\author{
ZhaoYing Zuo 1, 2, a, DeShan Tang ${ }^{1, b}$, Shangrui $\mathrm{Wu}^{2,}$, , Jian Sun ${ }^{2, d}$, \\ Yixian Wang ${ }^{2}$, e \\ ${ }^{1}$ School of Business, Hohai University, Nanjing 210000, China; \\ ${ }^{2}$ Rizhao Inspection \&Certification Co., Ltd Rizhao 276800, China. \\ a, bzuozhaoying0531@sina.com, c, d, ecliff0633@sina.com
}

\begin{abstract}
The framework of traditional certification market is based on the theory of one sided markets and ignored the two sided markets feature of certification market. The paper takes ISO9000 certification market as an example to illustrate characteristics of ISO9000 certification market through four aspects: demand complementarities, users heterogeneous, crossover network externalities and tilting pricing. Also the paper studies the key problems of the development of the market.
\end{abstract}

Keywords: ISO9000; certification body; two sided markets; platform pricing.

\section{基于双边市场理论的认证市场运行机制研究 \\ --以 1509000 认证市场为例}

左兆迎 ${ }^{1}{ }^{2}$, 唐德善 ${ }^{1}$, 吴尚䜭 ${ }^{2}$, 孙健 ${ }^{2}$, 王以宪 ${ }^{2}$

1. 河海大学商学院, 南京 中国;

2. 日照检验认证有限公司，日照 中国

摘 要: 传统的认证市场的框架是建立在单边市场理论基础之上的, 忽略了认证市场显著的 “双 边市场” 经济特征。该文以 1509000 认证市场为例, 通过需求互补性、用户异质性、交叉网络 外部性、倾斜式定价等四个方面说明了1509000认证市场运行的双边市场特征, 并就其市场发 展的关键问题进行研究。

关键词：1S09000认证, 认证机构；双边市场；平台定价

\section{1. 引言}

近年来中国的认证业务每年10\%左右递增，2014年认证机构颁发的现行有效认证证书 130 万余张, 和 2013 年相比增长了 $11.6 \%$, 其中IS09000证书 34 万余张, 同比增长 $1.7 \%$ 。认证市场 是连接被认证对象 (通常是企业, 为方便叙述, 下述用企业) 与上下游客户的桥梁和纽带, 是矫正信息不对称而造成市场失灵的重要组织形式。. Deaton B J (2004) 等运用信息经济学理 论建立了第三方认证机构的理论结构 ${ }^{(1)}$ 。Friederike Albersmeier (2009) 指出了第三方认 证机构的审核应该从检查表的审核转变为以控制风险为主的审核 ${ }^{(2)}$ 。苏秦等 (2010) 于认证服 务行业实际, 本研究构建起B2B情境下的服务质量测评模型 (3)。模型不仅测度了服务过程质量 和服务结果质量, 还将企业潜在的服务能力纳入到了测评体系当中。陈艳莹等 (2014) 从认证 产业的最优数量结构来探讨认证有效性问题, 通过一个改进的双重不完全信息重复博竕模型, 系统性地在外生集体声誉约束的框架下考察中国认证产业维持“质量卡特尔”的最优认证机构 数量问题 ${ }^{(4)}$ 。Ru Liu等 (2014) 将SERVQUAL服务模型应用于检验认证机构, 构建了检验认证 
机构的服务模型。通过调查中国检验认证集团 (CCIC) 的客户得出 “有形性” 距离客户感知 的差距最大 ${ }^{(5)}$

传统的对认证机构、认证市场的研究框架建立在单边市场理论基础，忽略了认证市场显 著的 “双边市场 (two-sided markets)” 特征。认证机构作为提供专业服务的平台，一端连 接被认证企业的产品与服务的 “供给方市场”，另一端连接上下游客户的 “需求方市场”， 两端市场相互作用、相互依赖。如中国出口到东南亚国家的产品很多时候要求作IS09000认证, 中国质量认证中心、SGS等认监委批准设立的认证机构即具有给出口企业进行 IS09000认证的 资格。本文借鉴双边市场理论，构建适用于IS09000认证市场的理论分析框架及分析认证市场 的“双边市场”特征。

\section{2. 双边市场理论}

Rochet\&Tirole (2003) 将双边市场定义为: 当平台交易量只受到平台向双边用户收取的交 易价格之和P受买方支付的交易价格（Pb）和为卖方支付的交易价格（PS）的影响时，该平台 就是单边市场; 若交易价格之和P恒定，价格结构 $(\mathrm{Pb} / \mathrm{Ps})$ 的变化对平台交易量会产生重大影 响, 该平台就属于双边市场（见图1）。 ${ }^{\left({ }^{6}\right)}$ 与传统的单边市场相比，双边市场具有以下四个特 征：（1）双边用户的需求互补性。在双边市场中，平台交易的实现是以双边用户对平台服务都 产生需求为根本前提的, 缺少任何一边用户都将导致另一边用户脱离平台交易并最终瓦解平 台结构。(2) 双边用户的异质性。异质性包括交易收益异质性和成员收益异质性, 前者强调双 边用户参与平台交易获得的收益不同, 后者关注同一边用户在参与平台交易时获得差异化收 益。(3) 交叉网络外部性, 它表达了一边用户规模的增加 (减少) 会扩大 (削减) 另一边用户规模 和收益的逻辑关系。(4) 倾斜式定价。在利润最大化的驱使下，倾斜式定价往往成为平台吸引 大量双边用户参与平台交易的占优策略, 即一边用户支付较高的交易价格, 另一边用户支付 较低或者不支付甚至支付负的交易价格。

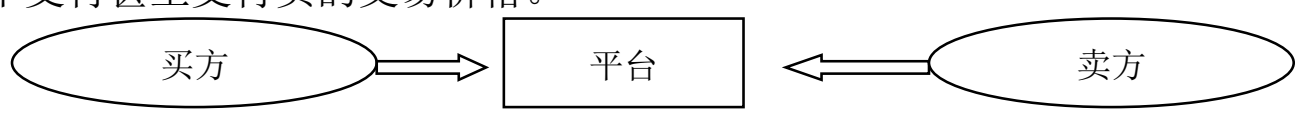

图1 双边市场的基本结构

Evans（2003）根据交易平台的功能将双边市场分为三类（见表1）：（1）市场制造型， 方便双边用户在平台上成交易，并通过交易平台提高搜寻交易对象的效率和交易成功的可能 性。（2）受众制造型。这种双边市场交易平台的主要职能是吸引观众读者等，企业才愿意在 交易平台上发布广告和产品的相关信息。（3）需求协调型。这类双边市场帮助两边的用户通 过交易平台来满足相互的需求.

\section{表1 双边平台分类及其定价}

\begin{tabular}{|c|c|c|c|c|c|c|}
\hline 产业 & 平台 & 类型 & 边 1 & 边 2 & $\begin{array}{c}\text { 收费较 } \\
\text { 少边 }\end{array}$ & $\begin{array}{c}\text { 平台利润 } \\
\text { 主要来源 }\end{array}$ \\
\hline 房地产 & 房产经纪 & 市场创造 & 买方 & 卖方 & 1 & 佣金 \\
\hline 房地产 & 房产经纪 & 市场创造 & 出租人 & 租赁者 & 1 & 佣金 \\
\hline 媒体 & 报刊 & 观众创造 & 读者 & 广告商 & 1 & 广告费 \\
\hline 媒体 & 电视 & 观众创造 & 观众 & 广告商 & 1 & 广告费 \\
\hline 媒体 & 门户网站 & 观众创造 & 上网者 & 广告商 & 1 & 广告费 \\
\hline 软件 & 操作系统 & 需求协调 & 用户 & 软件开发商 & 2 & 软件销售 \\
\hline
\end{tabular}

\section{ISO9000认证}

IS0/TC176技术委员会是IS0为了适应国际贸易往来中民品订货采用质量保证作法的需要 而成立的，该技术委员会在总结和参照世界有关国家标准和实践经验的基础上，通过广泛协 商，于1987年发布了世界上第一个质量管理和质量保证系列国际标准-IS09000系列标准。该 
标准的诞生是世界范围质量管理和质量保证工作的一个新纪元，对推动世界各国工业企业的 质量管理和供需双方的质量保证, 促进国际贸易交往起到了很好的作用IS09000是IS0发布的 12000 多个标准中最畅销、最普遍的产品。随着国际贸易发展的需要和标准实施中出现的问题, 特别是服务业在世界经济的比重所占的比例越来越大，IS0/TC176分别于1994年、2000、2008、 2014年对IS09000质量管理标准进行了全面的修订。第一阶段修订 1994年版, 对标准的内容 作了局部修改, 这次修改主要是对质量保证要求和质量管理指南的部分技术内容进行修订, 同时引入了一些新的概念和术语, 比如过程和过程网络、硬件、软件、流程性材料和服务等。 第二阶段修订 2000年版修改后的版的标准更加适用于各种组织、各个行业对标准的需求; 语 言明确、易于翻译和理解; 与其它管理标准如具有更好的兼容性, 并提出质量管理八项原则。 第三阶段修订 2008年版, 并没有增加新的要求, 并没有实质性的变化, 只是对实施了 2000 版增加了一些解释性的说明（核心结构见图2）。更加强调顾客满意及监管和测量的重要性, 强调了质量管理体系要求标准和指南标准的一致性。第四阶段修订 2015年版, 采用了10个章 节的 “高层结构” 、强调了组织的环境、扩大了对利益相关方的关注、加强了领导作用、提 出了对风险和机会的应对要求、淡化了对文件的指定性要求, 取消了质量手册、程序文件、 管理者代表等硬性要求。目前关于IS09000主要研究集中在如下几个方面, 首先是企业实施 IS09000认证的动机 ${ }^{(9)}$ (10), 企业通过IS09000认证和企业绩效的关系 ${ }^{(11)}{ }^{(12)}{ }^{(13)}$, 还有学者研 究IS09000认证的有效性问题 ${ }^{(14)}{ }^{(15)}$ 以及和其他体系认证的一体化问题 ${ }^{(16)}{ }^{(17)}$ (18)。没有文献 从双边市场角度进行研究。

\begin{tabular}{|c|c|}
\hline GB/T19000-2008 idt IS09000:2005 & 质量管理体系 基础和术语 \\
\hline GB/T19001-2008 idt IS09001:2008 & 质量管理体系 要求 \\
\hline GB/T19004-2009 idt IS09004:2009 & 质量管理体系 业绩改进指南 \\
\hline GB/T19011-2003 idt IS019011:2002 & 质量和（或）环境管理体系审核指南 \\
\hline
\end{tabular}

图2 2008版IS09000族标准的核心标准

\section{ISO9000认证市场的双边性质}

IS09000认证机构是对照IS09000标准对委托方进行审核的机构，对通过审核的企业颁发 IS09000认证证书。通过提供IS09000认证将被认证对象和上下游客户（包括消费者）联系起 来, 聚集到认证平台（认证机构）。通过IS09000认证机构专业公正的审核, 通过会谈、抽样、 查阅资料等方式证实企业达到了认证的要求。企业管理水平和生产能力得到有效提高, 在产 品标签上表明企业通过了 IS09000认证。产品或服务在市场上具有了一定的溢价, 上下游客户 愿意花费额外的价格购买该产品或服务。在收费策略上，认证机构的佣金通常基于供给方市 场（即企业）。

首先，需求互补性。认证机构提供认证服务是供需双方都对该服务产生需求为前提，供 需双方彼此依赖。缺少任何一方认证平台就失去意义。比如通过IS09000认证的企业和没有通 过IS09000认证的企业质量管理水平、员工质量意识等各方面都没有区别, 消费者也不会愿意 为通过IS09000认证的企业支付额外的费用, 大型企业招标也不会以通过IS09000认证作为必 备的招标资格，IS09000认证机构提供的认证服务将得不到相关方的认可，IS09000认证就丧 失了市场。

其次，用户异质性。认证服务供求双方的交易收益异质性体现如下：交易目的不同，被 认证对象进行认证是为了提高管理水平，而需求方则是对所购买产品和服务信赖的一种保证 (质量信号) ; 成本节约不同，认证机构可以降低上下游客户购买的信息搜寻成本，认证机构 有利于企业规范生产节约企业的生产材料浪费以及降低企业的采购、分包等风险。

再者, 交叉网络外部性 参与到认证市场进行交易的企业越多越大, 企业越有能力培养 经验丰富的审核员, 上下游客户的需求及潜在需求越容易得到满足, 认可IS09000认证的上下 游客户的规模就越大。其规模扩大又会进一步刺激更多的企业寻找认证机构的服务, 形成良 好的正反馈机制。 
第四，倾斜式定价 在认证市场中，IS09000认证机构每做完一单认证业务，企业即向认 证机构支付一定的佣金 (即交易价格)，而上下游客户不需要支付佣金。

最后结合Evans (2003) 的分析, IS09000认证市场属于第一类市场制造型, 即上下游客户 需要表征特定类型企业质量管理水平达到一定水平的质量符号时, IS09000认证机构应运而 生, 通过专业的审核给符合条件的企业颁发IS09000认证证书（即质量符号），撮合双方（特 定企业和上下游客户）达成了交易。

\section{5. 结论}

第一，交叉网络外部性说明了双边用户规模相互作用的反馈机制，但其发展依赖于参与 平台交易的用户规模是否达到临界值, 只有供给方或需求方的规模达到某一临界值, 才会引 起积聚效应。认证市场的建立初期需要解决的首要问题是如何吸引尽可能多的供给方和需求 方参与到平台交易中, 以及优先发展哪一边用户。由于企业为了不同的客户需求, 需要进行 多个种类的认证, 如食品企业同时通过IS09000和HACCP认证、化工企业需要同时进行IS09000、 IS014000认证、纺织企业同时需要IS09000、IS014000、SA8000等认证。新成立的认证机构应 提供丰富的认证种类, 同时可以开展企业所需要的检验业务, 吸引更多对IS09000认证的需求 方和潜在需求方加入到该平台。在发展过程中, 应不断提高自身的核心竞争力和审核员的审 核能力, 加强对审核员的培训, 对审核员的审核能力及道德素养进行跟踪评价, 优化审核员 的晋升通道，建立科学的审核员激励约束机制，维系和被认证企业的良好关系。

第二, IS09000认证机构成立初期, 可以通过赠送礼品、媒体宣传等方式吸引有认证需求 的客户以及挖掘潜在需求方加入该平台。之后需要关注供求双方的需求价格弹性, 以调整双 边用户的价格结构。残酷的市场竞争促使认证机构提高差异化服务水平, 同样的价格比服务, 实施品牌战略, 差异化服务能为认证机构提高附加值, 吸引更多具有较高支付能力的供求方 用户参与到平台交易中, 认证机构的涨价行为是以高附加值的服务和过硬的企业品牌为基础, 否则涨价行为可能导致企业经营陷于不利之地。

第三, 由于企业进行IS09000认证有多种认证动机, 有的企业纯粹是为了招投标需要或者 国外客户的需要才进行IS09000认证。由于不是以改善质量管理为目的, 有可能发生认证机构 迎合企业需要进行买卖证书的行为, 现场不进行检查或者缩短人天数, 严重扰乱了认证市场, 国家应通过执法检查、协会、媒体等多种方式加大对认证市场的治理力度, 倒逼IS09000认证 机构提升服务水平和认证能力。

\section{References}

[1] Deaton B J. A theoretical framework for examining the role of third-party certifiers[J]. Food Control. VOL.15( 2004),NO.8, p.615-619

[2] Friederike Albersmeier,Holger Schulze, Gabriele Jahn,Achim Spiller The reliability of third-party certification in the food chain: From checklists to risk-oriented auditing .Food Control. VOL. 20 (2009) NO.10, p 927-935,

[3] Su Qin, Cui YanWu, Dang JiXiang. A Study on Measuring Service Quality in B2B Context Based on Certification Service Industry, Business Review.VOL.22(2010) NO.7,p105-113

[4] Chen Yanying,Bao Zongke.Optimal Number Structure of Certification Industryhhina under Exogenous Collective Reputation Constraints.Journal of Finance and Economics,VOL.40 (2014), NO.8

[5] Liu, R., Cui, L., Zeng, G., Wu, H., et al.. Applying the fuzzy servqual method to measure the service quality in certification \& inspection industry. Applied Soft Computing, (2014) NO.26, p 508-512.

[6] Rochet, J., \& Tirole, J. Platform competition in two - sided markets.Journal of the European Economic Association, (2003 )NO.4, p 990-1029 
[7] Evans D S. The Antitrust Economics of Multi-Sided Platform Markets[J]. Yale Journal on Regulation, (2003), 20(2)

[8] Evans D S. The Antitrust Economics of Multi-Sided Platform Markets[J]. Yale Journal on Regulation, VOL.20,(2003), NO.2.

[9]İlkay M S. The effect of the ISO 9001 quality management system on the performance of SMEs[J]. International Journal of Quality \& Reliability Management, VOL.29(2012)NO.7, p 753-778.

[10] Valmohammadi Changiz; Kalantari, Mohsen. The moderating effect of motivations on the relationship between obtaining ISO 9001 certification and organizational performance TQM Journal. VOL. 27 (2015) NO. 5, p503-518.

[11] Sharma D S. The association between ISO 9000 certification and financial performance [J]. International Journal of Accounting Education \& Research, VOL.40(2005)NO.2:p151-172.

[12] Ullah B, Wei Z, Xie F. ISO Certification, Financial Constraints, and Firm Performance in Latin American and Caribbean Countries [J]. Global Finance Journal,. VOL. 25(2014)NO.3,p203-228.

[13] Feng.M, Samson D, Terziovski M. Relationship of ISO 9001:2000 quality system certification with operational and business performance: A survey in Australia and New Zealand - based manufacturing and service companies[J]. Journal of Manufacturing Technology Management,.VOL.19(2008)NO.1, p22-37.

[14] Psomas, E. The effectiveness of the ISO 9001 quality management system in service companies. Total Quality Management\& Business Excellence Journal VOL.24, (2013)NO..7-8, p769-781.

[15] Psomas E, Antony J. The effectiveness of the ISO 9001 quality management system and its influential critical factors in Greek manufacturing companies[J]. International Journal of Production Research,VOL.53( 2015)NO.7,p2089-2099

[16] Zutshi, A., Sohal, A., 2005. Integrated management system: the experiences of three Australian organisations[J].Journal of Manufacturing Technology Management VOL.16(2005) NO.2, p211-232

[17] Rocha, M., Searcy, C., Karapetrovic, S. Integrating sustainable development into existing management systems[J]. Total Qual. Manag. Bus. Excell. VOL.18(2007 )NO.1,p 83-92

[18] Bernardo M, Simon A, Tarí J J, et al. Benefits of management systems integration: a literature review[J]. Journal of Cleaner Production, VOL.14(2015),NO.1 ,p64-68. 